\title{
Eliza Grzelak
}

(Gniezno)

\section{ZRÓŻNICOWANIE WEWNĘTRZNE JĘZYKA ETNICZNEGO A UNIWERSALNE KONCEPCJE KODÓW WSPÓLNOTOWYCH. OD LINGWISTYKI DO SEMIOTYKI}

DOI 10.14746/SEG.2014.9.3

\begin{abstract}
The author collected the most important findings concerning the internal diversification of the ethnic language (using Polish as an example) and, treating those concepts as a starting point, set out to present the contemporary universal linguistic, discursive and communicative communities. While stressing the high diversification of codes within the communities, the author returns to the rhetorical, adequately defined concept of three styles. In her description of the code of communicative community, the author draws a reference to the communal nature of rendering the image of the world and highlights its intersemiotic, supraethnic and universal character.
\end{abstract}

\section{Key words}

ethnolinguistics, functional division of language, internal diversification of language, language communities, discursive communities, communication communities 
Żaden ze współczesnych badaczy nie ma wątpliwości, że język narodowy, będący systemem relatywizowanych kulturowo znaków służących komunikacji, nie jest strukturą jednorodną. Nawet jeśli porządek znaków jest tożsamy w różnych odmianach lub zbliżony, to relatywizacja kulturowa oraz użyteczność komunikacyjna wymogą, by język się różnicował w zależności od kontekstu komunikacyjnego.

Czynnikami wpływającymi na modyfikację języka są:

- typ sytuacji, np.: oficjalna, nieoficjalna;

- dominacja funkcji, np.: autoteliczna, informacyjna, emotywna;

- sytuacja nadawczo-odbiorcza komunikacji, np.: zawodowa, naukowa, środowiskowa;

— tożsamość etniczna, np.: język regionalny, ogólny.

Wszystkie te czynniki uwzględniali językoznawcy, próbujący usystematyzować zróżnicowanie wewnętrzne języka polskiego.

Zenon Klemensiewicz ${ }^{1}$ uznał, że język narodowy tworzą języki regionalny i ogólny, oba kształtują gwarę miejską, natomiast język regionalny obejmuje język regionalny konwersacyjny i język regionalny artystyczny. Język ogólny tworzą języki: potoczny i literacki, literacki zaś uwzględnia trzy odmiany: język artystyczny, język naukowy i język normatywno-dydaktyczny; język potoczny z kolei dzieli się na język konwersacyjny i monologowy.

Antoni Furdal ${ }^{2}$, analizując zróżnicowanie wewnętrzne polszczyzny, uwzględnił także dodatkowe czynniki systemowe, np. modyfikacje semantyczne, czyli ograniczenie znaczeniowe terminów naukowych i profesjonalizmów oraz poszerzanie możliwości interpretacyjnych w ramach języka artystycznego. Uznał, że ta cecha pozwala wyodrębnić język naukowy, język artystyczny oraz neutralny w tym zakresie język potoczny. Dostrzegł także, że kanał przekazu decyduje o formie komunikatu, dlatego wyróżnił język mówiony i pisany, choć nie uwzględnił, że kaszubszczyzna, jako język ludowy, była znana także w postaci pisanej. A. Furdal ${ }^{3} \mathrm{w}$ większym stopniu niż Z. Klemensiewicz ${ }^{4}$ podkreślał uwarunkowania socjalne języka. Zauważył duży stopień jednorodności języka

${ }^{1}$ Z. Klemensiewicz, O różnych odmianach współczesnej polszczyzny, Warszawa 1953.

${ }^{2}$ A. Furdal, Językoznawstwo otwarte, Wrocław 2000.

${ }^{3}$ Ibidem.

${ }^{4}$ Z. Klemensiewicz, op. cit. 
narodowego, zwrócił także uwagę na fakt, że im większe rozwarstwienie socjalne społeczeństwa, tym widoczniejsze i głębsze pęknięcia wewnątrz języka wykorzystywanego przez to społeczeństwo w celach komunikacyjnych.

Aleksander Wilkoń ${ }^{5}$ omawiając typologię odmian języka polskiego, odwołał się zarówno do spostrzeżeń Z. Klemensiewicza ${ }^{6}$, jak i A. Furdala ${ }^{7}$. Zaakceptował klemensiewiczowski termin „,język ogólny”, który nie był dla niego równoważny z określeniami: język literacki, język inteligencji. Odrzucił natomiast klemensiewiczowskie rozumienie języka narodowego, słuszniejsza wydała mu się w tym przypadku propozycja Stanisława Urbańczyka ${ }^{8}$, przypominająca o etniczności języka narodowego. Dostrzegł także dwuznaczność terminu język regionalny oraz zakwestionował zasadność wyodrębniania języka monologowego i języka konwersacyjnego. Doszukiwał się różnic między nimi na poziomie struktury tekstu. Wątpliwości budził również szeroko rozumiany język potoczny.

Za godną zainteresowania uznał krzyżową klasyfikację A. Furdala9 ${ }^{9}$ Odwołując się do tej propozycji, wyodrębnił w ramach współczesnego języka polskiego język ogólny i gwarę ludową, różniące się porządkiem systemowym, czyli fonologicznie, morfologicznie oraz syntaktycznie.

A. Wilkoń ${ }^{10}$, analizując różne czynniki socjalne, obok języka ogólnego, języków regionalnych i języków mieszanych wyodrębnił także: socjolekty, psycholekty, biolekty oraz profesjolekty. Socjolektami nazwał odmiany językowe weryfikowane w ramach klas społecznych, warstw, środowisk i grup zawodowych ${ }^{11}$. Psycholekt odzwierciedlał naturę psychiczną użytkowników języka, głównie nadawców ${ }^{12}$, biolekt zaś identyfikował płeć oraz wiek. Profesjolekt zastąpił przywoływaną u innych odmianę naukową, normatywno-dydaktyczną czy zawodową ${ }^{13}$.

${ }^{5}$ A. Wilkoń, Typologia odmian językowych współczesnej polszczyzny, Katowice 2000, s. 14.

${ }^{6}$ Z. Klemensiewicz, op. cit.

${ }^{7}$ A. Furdal, op. cit.

${ }^{8}$ S. Urbańczyk, Rozwój języka narodowego. Pojęcia i terminologia, Prace z dziejów języka polskiego, Wrocław-Warszawa-Kraków-Gdańsk 1979, s. 9-33.

${ }^{9}$ A. Furdal, op. cit.

${ }^{10}$ A. Wilkoń, op. cit.

${ }^{11}$ Ibidem, s. 87-99.

${ }^{12}$ Ibidem, s. 103-104.

${ }^{13}$ Ibidem, s. 99-101. 
Renata Przybylska zwróciła szczególną uwagę na różnorodność czynników branych pod uwagę w klasyfikacji wewnętrznych odmian języka polskiego. Najczęściej według niej przywoływane były w przedstawionych wyżej analizach:

"- zasięg geograficzno-terytorialny języka;

- zasięg kontaktu językowego: prywatny, lokalny, ogólnopolski;

- sposób przekazywania komunikatu językowego: mówiony (ustny) lub pisany;

- typ sytuacji komunikacyjnej: oficjalna lub nieoficjalna;

- szczególna sfera społeczna komunikowania się:

- życie codzienne (rodzina, znajomi itp.);

- życie zawodowe;

- udział w życiu odrębnych grup społecznych lub subkultur;

- administracja i urzędy;

- nauka;

- polityka;

- religia;

- reklama;

- zakres tematyczny wypowiedzi: ogólny lub specjalistyczny;

- charakterystyka socjalna uczestników komunikacji językowej:

- płeć;

- wiek;

- wykształcenie;

- miejsce zamieszkania: miasto czy wieś;

- poziom aspiracji społecznych;

- stopień zażyłości łączący rozmówców"14.

Większość z tych czynników wziął po uwagę także Stanisław Grabias ${ }^{15}$, który analizując zachowania społeczne i towarzyszące im zachowania językowe, uznał, że relacje między językiem a społeczeństwem można sprowadzić do dwóch tez:

- język jako twór społeczny, podobnie jak inne społeczne zjawiska, nie daje się tworzyć dowolnie, ponieważ zależny jest od użyć zbiorowych;

\footnotetext{
${ }^{14}$ R. Przybylska, Wstęp do nauki o języku polskim, Kraków 2003, s. 47.

${ }^{15}$ S. Grabias, Język w zachowaniach społecznych, Lublin 2003.
} 
— język jest narzędziem komunikacji i interpretacji rzeczywistości, dlatego warunkuje zachowania indywidualne i społeczne ludzi.

S. Grabias przypomniał także o znaczącej roli kompetencji językowej, którą cechuje określony stopień kreatywności, gramatyczności, akceptabilności oraz interioryzacji. Kreatywność dla Noama Chomskiego to zdolność wykorzystania ograniczonego zbioru elementów do tworzenia nieskończonej liczby nowych zdań, spójnych z nową sytuacją mówiącego ${ }^{16}$. Gramatyczność postrzegał jako poprawność formalną i znaczeniową zdań. Akceptabilność zaś to zdolność użycia języka rodzimego w celu osiągnięcia poprawnej wypowiedzi, zgodnej $\mathrm{z}$ obowiązującą normą. Interioryzacja ujawniała się według niego w procesie nieświadomego opanowywania języka ojczystego.

Socjolingwiści, także S. Grabias, nie ograniczali się do opisu odmian językowych uzależnionych od społecznego statusu użytkowników. Interesowało ich także, jak przebiega proces tworzenia grup społecznych, warunkowanych określonym użyciem języka ${ }^{17}$. Punktem wyjścia takich analiz może być przebieg procesów społecznych i ich odzwierciedlenie w kontaktach werbalnych i niewerbalnych, czyli sposób komunikowania się, można także badać komunikację wewnątrz większej struktury językowej, np. narodowej, i na podstawie tych badań wskazać granice dzielące społeczeństwo. Pomocna w obu metodach jest teoria kodów Basila Bernsteina ${ }^{18}$.

Zaproponował on, by w ramach języka etnicznego wyodrębnić różnorodne kody językowe. Zwrócił też uwagę, że można wskazać dwa typy kodów: ograniczone i rozwinięte. W obrębie stałej, pierwotnej grupy sprawdza się według niego kod ograniczony. Natomiast kod rozwinięty, nieograniczający kompetencji użytkownika, pozwala na komunikację z przedstawicielami innych grup. B. Bernstein podkreślał, że kody:

- odzwierciedlają uwarunkowania psychiczne nadawcy;

- są narzędziem opisu rzeczywistości, różnią się między sobą stosunkiem do świata i rzeczy, utrwalonym w znaczeniach słów oraz porządku werbalnym;

\footnotetext{
${ }^{16}$ Ibidem, s. 34.

${ }^{17}$ Ibidem, s. 94.

${ }^{18}$ B. Bernstein, Socjolingwistyka a społeczne problemy kształcenia, [w:] M. Głowiński (red.), Język i społeczeństwo, Warszawa 1980, s. 90.
} 
- są efektem procesów socjalizacyjnych, decydują więc o socjalnym statusie nadawcy oraz opisują jego relacje społeczne ${ }^{19}$.

Pierwsze dwie tezy, szczególnie druga, odsyłają nas do badań etnolingwistycznych i językowego obrazu świata, które mogą stanowić fundament współczesnego rozumienia wspólnoty komunikacyjnej jako podstawowej jednostki składowej języka etnicznego.

Identyfikacja kodów ściśle powiązana z relacjami społecznymi stanowić mogła podstawę dla funkcjonalnego podziału języka, opracowanego na potrzeby metodologii strukturalnej i typologii omawianych na wstępie. Jednak perspektywa postrzegania języka zaproponowana przez B. Bernsteina była odmienna - najważniejsza stała się relacja języka do świata ${ }^{20}$.

Teoria kodów B. Bernsteina ${ }^{21}$ dowiodła, że dotychczasowe propozycje typologiczne, łączące wymogi strukturalizmu i wskazania socjolingwistyczne, były niewystarczające; ich twórcy dążyli do ostatecznego wskazania zamkniętych, wyraźnie zdefiniowanych odmian językowych, które mimo obszernych charakterystyk wymykały się próbom dookreślenia.

Ten niedosyt w zakresie ostateczności opisu pozwala przypuszczać, że wskazywane odmiany nie są zamknięte, lecz krzyżują się, oraz że ich różnice uwidaczniają się nie tylko w strukturze formalnej przekazu werbalnego, lecz jak podkreślali B. Bernstein oraz etnolingwiści, także na poziomie semantyki. Spostrzeżenie socjolingwistów, że język charakteryzuje status społeczny nadawcy i odbiorcy, a także ich relacje społeczne, oraz psycholingwistów, że język obrazuje stan psychiczny nadawcy, czyli między innymi jego emocjonalny stosunek do rzeczywistości, uzupełnili etnolingwiści, zwracając uwagę na fakt, że język przede wszystkim opisuje świat, w którym żyją użytkownicy języka, czyli jest zwierciadłem ich kultury.

Punktem wyjścia do postrzegania kodu wspólnotowego jako zwierciadła kultury danej wspólnoty oraz narzędzia jej kreacji była teoria Sapira-Whorfa mówiąca, że język każdej odrębnej grupy społecznej, będący jej wytworem, narzędziem myślenia i komunikowania się, organizuje sposób postrzegania świata, czyli w indywidualny sposób kreuje go. Konsekwencją tej tezy było założenie, że wspólnoty budujące odrębne systemy językowe postrzegają świat

\footnotetext{
${ }^{19}$ S. Grabias, op. cit., s. 50.

${ }^{20}$ B. Bernstein, op. cit., s. 83-119.

${ }^{21}$ Ibidem.
} 
rozmaicie. Edward Sapir dostrzegł, że ludzie zarządzani są przez swój własny kod językowy, czyli żyją w świecie wykreowanym przez nawyki językowe ${ }^{22}$. Benjamin Lee Whorf zwrócił szczególną uwagę na subiektywność postrzegania świata, które zauważalne jest na poziomie lingwistycznym ${ }^{23}$.

Hipotezy etnolingwistyczne zgodne były z filozoficznym obrazem kodu i wspólnoty posługującej się nim, powstałym na bazie teorii poznania W. Humboldta i Johanna Gottfrieda Herdera. J.G. Herder dostrzegł, że język wyznacza granice poznania człowiekowi, który myśli za pomocą słów ${ }^{24}$. Uważał, że w języku zawarta jest wiedza wynikająca $\mathrm{z}$ doświadczenia pokoleń oraz że użyciu języka towarzyszy projekcja społecznych doświadczeń, tkwiących w językowych stereotypach, czyli język jest według niego nośnikiem pamięci społecznej. Stwierdził między innymi, że język, który narzuca formę myślom, tworzy obraz rzeczywistości zgodny z poglądem utrwalonym w danym języku. W. Humboldt zaproponował, żeby ich teorią poznania zainteresowali się lingwiści. Dostrzegł on rangę subiektywnego oglądu świata; zwrócił uwagę, że nikt $z$ nas nie postrzega przedmiotu realnego, lecz obraz wytworzony w naszym przeświadczeniu. Doszedł do wniosku, że idiolektalne, subiektywne obrazy przedmiotów tworzą wspólny obiektywizujący się obraz rzeczywistości charakterystyczny dla wspólnoty etnicznej ${ }^{25}$. Podkreślał także, że człowiek ze swoją możliwością poznania uwięziony jest w kręgu języka wspólnotowego. W związku z tym, jeśli chce poznawać świat odmiennie, musi przeniknąć do innego kręgu językowego.

Metodologiczną konsekwencją wyodrębnienia wspólnoty językowej było przyjęcie, że język to jeden $z$ wytworów ludzkich, który uzewnętrznia się w trakcie użycia. Takie rozumienie wspólnoty językowej zakładało istnienie idealnego nadawcy i odbiorcy, posiadających wzorcowe kompetencje językowe. Wątpliwości budziło i nadal budzi jednak wewnętrzne zróżnicowanie wspólnot, na które zwrócił uwagę Basil Bernstein i które było przedmiotem badań wspomnianych na wstępie językoznawców. Dowodziło ono, że niemożliwe jest odwoływanie się do jednolitej i jednorodnej kompetencji językowej członków danej wspólnoty. Istniał także problem bilingwizmu, dyglosji oraz fakt, że jeden

\footnotetext{
${ }^{22}$ E. Sapir, The Status of Linguistics as a Science, [w:] D. Mandelbaum, Selected Writings of Eduardo Sapir in Language, Culture and Personality, Berkeley-Los Angeles 1951, s. 160-166.

${ }^{23}$ A. Schaff, Język a poznanie, Warszawa 1967, s. 103.

${ }^{24}$ Ibidem, s. 15.

${ }^{25}$ W. Humboldt, Über die Verschiedenheit des menschlichen Sprachbaues und ihren Einfluss auf die geistige Entwicklung des Menschengeschlechts, [w:] idem, Gesammelte Schriften 6, Berlin 1907, s. 179.
} 
użytkownik danego języka uczestniczy w ramach tegoż języka w więcej niż jednej wspólnocie społecznościowej. Kwestionując postulat, że to język definiuje wspólnoty ludzkie, stworzono koncepcję kompetencji komunikacyjnej oraz interakcyjnej. Pozwalało to w granicach szeroko pojmowanej wspólnoty językowej, którą wyznaczał dany system, wskazać wiele otwartych wspólnot komunikacyjnych oraz w ramach uniwersalizacji rozszerzyć zasób znaków, obsługujących dany kod, o znaki niewerbalne, co w konsekwencji doprowadziło do powstania ponadetnicznych, intersemiotycznych wspólnotowych kodów komunikacyjnych.

„Relacje społeczne oraz wytworzone w ramach procesów komunikacyjnych teksty utrwalają wspólny stosunek do rzeczywistości, czyli kształtują własny wspólnotowy obraz świata, który zgodnie z tezą W. Humboldta, będąc subiektywnym w indywidualnej kreacji, obiektywizuje się na poziomie wspólnotowym. Gradacja obiektywizacji jest różna w zależności od zakresu wspólnotowego, im szerszy zakres, tym obiektywizacja wyraźniejsza. Różnorodność relacji wewnątrzwspólnotowych pociąga za sobą konieczność modyfikowania kodu wspólnotowego. Modyfikacja ta warunkowana jest funkcjonalnością zdarzenia komunikacyjnego, pojęcie funkcjonalności w tym wypadku obejmuje zróżnicowanie kompetencyjne w zakresie kodu nadawcy i odbiorcy, treść i cel przekazu oraz kontekst sytuacyjny"26.

Przyjęcie tej tezy oznaczało, że zgodnie z wcześniej zaprezentowanymi poglądami socjolingwistów i etnolingwistów każda odrębna grupa społeczna, powiązana określonymi relacjami społecznymi, tworzy własne intersemiotyczne teksty, które budują indywidualny system komunikacyjny, czyli stanowią podstawę własnego sposobu porozumiewania się. Relacje te mogą mieć podłoże hobbystyczne, zawodowe czy środowiskowe, mogą także dotyczyć grup wykorzystujących własny biolekt.

Rangę tekstu jako identyfikatora dostrzegł John M. Swales ${ }^{27}$, który stworzył koncepcję wspólnoty dyskursu. Uznał on, że istotę wspólnoty dyskursywnej stanowią cele społeczne, które przyświecają jej członkom. By móc komunikować się w ramach danej wspólnoty dyskursywnej, należy posiadać kompetencje, umożliwiające tworzenie i odbiór produkowanych przez tę wspólnotę tekstów. Taka koncepcja, która definiuje wspólnotę przez wytwarzane przez nią teksty,

\footnotetext{
${ }^{26}$ E. Grzelakowa, W poszukiwaniu Edenu. Językowo-kulturowy obraz współczesnego polskiego ogrodu ozdobnego. Kreacja czasu i przestrzeni, Gniezno 2008, s. 18.

${ }^{27}$ J.M. Swales, Genre Analysis: English in Academic and Research Settings, Cambridge 1990.
} 
jest bardzo przydatna w opisie relacji wspólnot zinstytucjonalizowanych; pomaga opisać każdą komunikację w organizacji.

Wspólnota dyskursu zakłada różny stopień wtajemniczenia jej członków, różną ich kompetencję w zakresie języka. Wspólnota ta akceptuje również członkostwo w więcej niż jednej wspólnocie, co znajduje odzwierciedlenie w postępującej uniwersalizacji niektórych wspólnot, przekraczających granice języka etnicznego. Jest to zgodne $\mathrm{z}$ istotną cechą wspólnot dyskursywnych mogą one powstawać ponad wspólnotami językowymi, bez względu na rodzimy język jej członków. Pojęcia naród, etniczność zastępowane są wspólnotą celów; fundamentem relacji jest konwencja. Wydzielenie wspólnot dyskursywnych pozwala pominąć problem opozycji język rodzimy-język obcy ${ }^{28}$.

Narastająca tendencja różnicowania wewnętrznego wspólnot dyskursywnych pozwoliła badaczom wskazać wspólnoty kultury, które łączą sieci więzi społecznych lub systemy kulturowe. Tak rozumiane wspólnoty kultury wymogły między innymi zredefiniowanie pojęcia kultura. Konieczne okazało się wskazanie kultur ukierunkowanych na doraźne, specyficzne systemy aksjologiczne, doświadczenia i wyobrażenia o świecie ${ }^{29}$.

Postępujące podziały społeczne, wywołane różnorodnymi czynnikami, skutkują wyodrębnianiem się węższych wspólnot: wspólnot stylu życia, struktur paraplemiennych, do których przynależność jest definiowana z perspektywy postaw, potrzeb, pozycji społecznej i oczekiwań ${ }^{30}$.

Wszystkie te koncepcje, potwierdzone badaniami interdyscyplinarnymi, mogą być brane pod uwagę w dalszych badaniach nad komunikacją interpersonalną.

Pozostaje jednak otwarte pytanie, czy można w wystarczającym i komplementarnym stopniu opisać wewnętrzne zróżnicowanie kodu wspólnotowego bez względu na typ wspólnoty. Nadreprezentatywność w języku danego typu tekstów, wewnętrznych odmian biolingwalnych i kodów funkcjonalnych utrudnia opis całościowy. Pamiętając, że przekaz w ramach wyodrębnionych wspólnot komunikacyjnych jest różnicowany/modyfikowany podobnie jak w obrębie języka etnicznego, i że różnice te są konsekwencją sytuacji nadawczo-odbiorczej, uwzględniając także cel i kontekst komunikacyjny przekazu,

${ }^{28}$ A. Duszak, Języki, kultury, wspólnoty, [w:] A. Kopczyński, U. Zaliwska-Okrutna, Język rodzimy a język obcy. Komunikacja, przekład, dydaktyka, Warszawa 2002, s. 7-23.

${ }^{29}$ H. Clark, Communities, Commonalities, and Communication, [w:] J. Gumperz, S. Levinson, Rethinking Linguistic Relativity, Cambridge 1996, s. 324-355.

${ }^{30}$ L. Dyczewski, Kultura polska w okresie przemian, Lublin 1995. 
można uprościć opis kodu wspólnotowego, wskazując trzy retoryczne style komunikowania się: wysoki, średni i niski, które obsłużą wszelkie zdarzenia komunikacyjne oraz pozwolą zrealizować ich podstawowe funkcje.

Styl wysoki w ramach komunikacji wspólnotowej pojawia się w tekstach o dominującej funkcji autotelicznej, tekstach podniosłych, realizowanych w sytuacjach specjalnych. Styl średni służy komunikacji o dominującej funkcji informacyjnej, pozwala przekazywać wiedzę, prowadzić dyskurs naukowy i dydaktyczny. Styl niski, służący komunikacji codziennej, minimalnie wyposażony w profesjonalizmy i środki artystyczne, wzmacnia więzi wspólnotowe. Taki podział w sposób adekwatny odzwierciedla stosunki społeczne, konteksty komunikacyjne i cele przekazu w obrębie wydzielonej wspólnoty komunikacyjnej, którą łączą: zakres tematyczny komunikacji, problematyka przekazu i jego cele. Uczestnicy komunikacji specyficznych/wspólnotowych stają się jednocześnie jej okazjonalnymi lub stałymi członkami. Dowodzą tego zasady funkcjonowania wspólnoty szkolnej, w ramach której można wyodrębnić wspólnotę nauczycieli i uczniów. Styl wysoki zarezerwowany jest dla uroczystości szkolnych i przekazów okazjonalnych, styl średni dla procesu komunikacji dydaktycznej, styl niski dla komunikacji pozadydaktycznej. Wspólnota prawników również wykorzystuje wszystkie trzy style, choć dotychczasowa analiza języka prawa uwzględniała język prawniczy - język prawników, omówienia prawa, język prawny - język dokumentów prawnych, jednak pomijała język komunikacji codziennej prawników oraz innych uczestników tej sfery komunikacji społecznej, niebędących prawnikami w sensie formalnym, np. studentów prawa, osób przesłuchiwanych, policjantów. Dlatego nawet w tej wspólnocie właściwszy, z punktu widzenia socjologii, etnologii i lingwistyki, jest właśnie podział stylowy, który obejmie wszelkie przekazy. Dowodzi tego komunikacja wspólnotowa ogrodników. Obejmuje ona różne formy przekazu: naukowy, popularnonaukowy, artystyczny, codzienny; różne typy komunikacji: medialną i bezpośrednią, publiczną, interpersonalną i masową. Biorą w niej udział naukowcy, publicyści, osoby zawodowo zajmujące się ogrodami, amatorzy/pasjonaci ogrodnictwa, osoby posiadające ogród lub tylko interesujące się ogrodem, kobiety i mężczyźni, starsi i młodsi. Taka odmienność sytuacji nadawczo-odbiorczych generuje pytanie, co w takim razie powoduje, że przy tak dużym wewnętrznym zróżnicowaniu uczestników komunikacji i form przekazu, nadal możemy mówić o jednej wspólnocie komunikacyjnej. Otóż wskazane wyżej różnice nie mają wpływu na obraz świata zawarty w różnych wewnątrzwspólnotowych przekazach/tekstach, to właśnie on stanowi podstawę więzi grupowej. Bez względu na to, kto do kogo mówi, gdzie, w jakim celu i o czym, zawsze w ramach danej 
wspólnoty komunikacyjnej ma na uwadze wspólny system wartości, wspólny sposób kategoryzowania oraz jednakowy punkt widzenia. Ta wspólnota postrzegania i waloryzowania utrwalona jest w konotacjach pojęć tworzących zasób leksykalny danego kodu. Każdy członek wspólnoty dysponuje wiedzą, wynikającą ze wspólnotowego doświadczenia pokoleń, każdemu użyciu kodu wspólnotowego towarzyszy projekcja społecznych doświadczeń, tkwiących w językowych stereotypach. Powołując się na teorię poznania W. Humboldta, można rzec, że jeśli chce się właściwie i komplementarnie zrozumieć teksty kultury wykreowane przez członków danej wspólnoty, należy przeniknąć do tej wspólnoty i poznać jej kod wspólnotowy.

Takie rozumienie wspólnot i ich wewnętrznych modyfikacji upraszcza także podział funkcjonalny języka etnicznego. Pozwala uniknąć np. pytania, czy mamy we współczesnej komunikacji do czynienia z etnicznym językiem religijnym, czy stylem religijnym w ramach tegoż języka etnicznego, gdyż zgodnie Z wyżej sformułowaną tezą jest to system werbalny, będący częścią wspólnotowego kodu komunikacyjnego osób wierzących. Nie można jednak w zgodzie $\mathrm{z}$ tą tezą opracować nawet $\mathrm{w}$ ramach jednego języka etnicznego typologii wspólnotowej w sposób ostateczny i zamknięty. Rozwój cywilizacyjny sprawia, że każdy język etniczny obsługuje coraz większą grupę przekazów specjalnych, wokół których powstają kolejne wspólnoty. Kształtowanie się takiej młodej wspólnoty - wspólnoty informatycznej - mogliśmy obserwować na przełomie wieków. Początkowo jej kod był wyraźnie ograniczony, jednak wzrastająca liczba jego stałych użytkowników sprawiła, że stał się dynamicznym kodem otwartym. Wspólnota ludzi zafascynowanych informatyką rosła, rozszerzała się, modyfikując się wewnętrznie. Nadal jednak łączy jej członków to, co istotne jest w każdej wspólnocie komunikacyjnej — wspólnotowy sposób postrzegania świata, szczególnie jego system aksjologiczny.

Jak zauważyłam, opisując wspólnotę dyskursywną, w dobie dynamicznej globalizacji niektóre wspólnoty uniwersalizują się. Podobny sposób obrazowania i tożsamy system aksjologiczny mają wspólnoty religijne, np. chrześcijanie $\mathrm{w}$ różnych krajach, podobne zjawisko można zaobserwować w ramach wspólnoty ogrodniczej, medycznej oraz wspólnoty prawniczej. Są to kody wspólnotowe o bogatych tradycjach, jednak podobne procesy zachodzą także w ramach najmłodszych wspólnot, np. informatycznej.

Występują także wspólnoty pośrednie, które obejmują przedstawicieli, posługujących się więcej niż jednym językiem etnicznym, jednak nie mają one charakteru uniwersalnego, np. odrębną wspólnotę tworzą obywatele państw posttotalitarnych. W specyficzny sposób rozumieją oni pojęcia: wolność, de- 
mokracja, partia, komunizm, socjalizm, odmiennie postrzegają granice wolności słowa, posiadają też własną hierarchię wartości, w której historia, przeszłość lokalizowane są bardzo wysoko. Ta specyfika wspólnotowa nie jest jednak trwała, gdyż w miarę dorastania kolejnych pokoleń uczestniczących w komunikacji publicznej, pamięć społeczna doznań totalitarnych będzie się zacierała i te specyficzne relacje społeczne upodobnią się do relacji interpersonalnych typowych dla społeczeństw ustabilizowanych ustrojowo.

Zaprezentowane wyżej wspólnotowe kody komunikacyjne, wyodrębnione nie tylko $\mathrm{w}$ wyniku analiz lingwistycznych, jak w przypadku typologii zaprezentowanych na wstępie, a w znacznie większym stopniu kulturowych, obejmują obok znaków werbalnych także wszelkie inne znaki, służące komunikacji wewnątrzwspólnotowej. Są to znaki warunkowane antropocentryzmem współczesnej komunikacji, czyli tego typu przekazy, które człowiek może samodzielnie zinterpretować. Należą do nich znaki odbierane przez zmysł wzroku - barwa, motyw, kompozycja, linia, język ciała, zmysł słuchu — znaki cywilizacyjne i naturalne, zmysł smaku, zmysł węchu, zmysł dotyku. Z odmianą funkcjonalną języka etnicznego mogą więc być utożsamiane tylko w zakresie przekazu werbalnego w obrębie jednego języka etnicznego, gdy uniwersalizują się i przekraczają granice kodów etnicznych oraz uruchamiają komunikację na wszystkich poziomach semiotycznych, stają się jednym z kodów komunikacyjnych typologizujących komunikację społeczną wewnątrz zdefiniowanych kultur i na ich granicach.

To dowodzi, że chcąc opisać kod wspólnotowy, nie możemy sięgać wyłącznie do zamkniętych metod lingwistycznych, bardziej komplementarny obraz komunikacji wspólnotowej uzyskamy, wykorzystując także narzędzia wypracowane przez semiotykę. Odpowiedzią na problemy lingwistów może stać się opis interdyscyplinarny.

\section{Eliza Grzelak}

INTERNAL DIVERSIFICATION OF ETHNIC LANGUAGE AND

UNIVERSAL CONCEPTS OF COMMUNITY CODES. FROM LINGUISTICS TO SEMIOTICS

\section{Summary}

In the article, the author suggests an internal division of the community codes, regardless of their ethnic extent. She sets out from a critical presentation of functional divisions of Polish which have been advanced so far, and which rely on the 
structural perception of language. Demonstrating their inadequacy and the frequent modifications, the author draws on the sociolinguistic theories of B. Bernstein, ethnolinguistic concepts of Sapir-Whorf and the philosophical notions of W. Humboldt and J.G. Herder in order to show that the cultural factor should be the basis of distinguishing between internal community codes.

She also draws attention to the universalisation of the community codes which, due to globalisation processes, begin to function on the boundaries of ethnic languages.

The author concludes that codes used in community communication of populations isolated not only through linguistic analyses but most of all in the course of cultural differentiation, include, apart from the verbal signs, all other signs which serve the communication within the community. Consequently, they may be identified with the functional variant of ethnic language only within the field of verbal transmission. However, when they become universal and go beyond the limits of ethnic codes as well as trigger communication on all semiotic levels, they become one of the communication codes which typologize social communication within defined cultures and at their boundaries. 